EUROPEAN HONORS COUNCIL

Note

\title{
Creating community during the COVID-19 pandemic: Honors makes
}

\section{a case online}

\author{
Marca Wolfensberger ${ }^{1 *}$ and Marte Vroom ${ }^{2}$
}

1 Utrecht University/Hanze University of Applied Sciences, the Netherlands; m.v.c.wolfensberger@uu.nl

2 Utrecht University/Hanze University of Applied Sciences, the Netherlands; m.m.vroom@students.uu.nl

*Correspondence: m.v.c.wolfensberger@uu.nl

Received: 20 May 2020; Accepted: 22 June 2020; Published: 27 June 2020

Keywords: online education; community building; social bonding; COVID-19

\section{Introduction}

The coronavirus created a new reality: a digital revolution has transformed education at universities around the world within a couple of weeks. In most European countries, the governments obliged universities to cancel face-to-face education because of the high health risks involved. This shift was needed because of the risk of infection with COVID-19. Arguments that were given to cancel face-to-face education were the age of the students, the international body of students and a large amount of traffic involved. Before the COVID19 pandemic, most honors educators would agree that honors education thrives on face-toface encounters. Creating a committed community is one of the main pillars of honors teaching (Wolfensberger, 2012). In this article, we describe how the honors program of the Human Geography and Spatial Planning department of Utrecht University, a research university in the Netherlands, has adapted to the current pandemic to meet the needs of the honors students. The aim of this article is to explain how the digitalization of education, due to the coronavirus, has led to an adapted honors course with a focus on wellbeing and creating community.

\section{COVID-19: measures and its effects}

On February $27^{\text {th }}, 2020$, the first official infection with COVID-19 was found in the Netherlands. What followed was a rapid spread of the virus, which resulted in the first measures taken on the $11^{\text {th }}$ of March. In the Netherlands, all universities firstly had to cancel their face-to-face courses with a larger audience than 100 people, then 30 , and then all 
courses within a few weeks. At the time of writing, large gatherings-common at universities-are still forbidden.

At Utrecht University, teachers and other staff organized themselves and made sure most of the face-to-face courses offered at the university were offered via digital platforms. The whole academic community had to change overnight into an "online community." With over 30,000 students (Utrecht University, n.d.), this meant a lot of work. As Utrecht University already has TAUU (a community for teachers, https://tauu.uu.nl/) most faculty members got support on how to organize themselves. Also, a lot of information on remote teaching has been collected and offered online (see https://www.uu.nl/en/education/quality-andinnovation/remote-teaching).

The board of the university informed teachers and students on the progress of measures on a weekly basis. After a few weeks, task forces were also implemented as it was assumed that the teaching in the 2020-2021 academic year will still be (partly) online.

The workload for the teachers is high. It is not easy to learn new digital skills while "surviving" one's teaching task. This digital revolution overnight asks a lot of the people involved. People have to make choices. For instance, teachers gave priority to organizing content remotely or creating new exams instead of interactive teaching or deep learning. How to create community or to stimulate professional and personal development was not a first priority.

As many considered the transformation delivered by the staff a great piece of work, the hashtag \#UUGotThis went viral throughout the university. However, one of the biggest concerns was the quality of education. Some critics suggest that students graduating during the COVID-19 pandemic will receive a so-called "corona diploma": a diploma of less quality due to the sudden switch to online education. Additionally, students fear that they cannot graduate this academic year due to several reasons, such as courses being cancelled but also internships that cannot be completed. This concern is why most of the attention is given to students who are in dire need. Honors students are able and willing to do more than the regular program can offer. As such, they are often not seen as students at risk.

A lot of students could follow all courses as they planned and could do their exams. However, soft skills courses, lab work, fieldwork and internships were difficult to replace. A lot of the teaching under coronavirus is concentrating on the knowledge and the content.

\section{Consequences for students at Utrecht University}

In the Netherlands, students are being confronted by loneliness due to the measures taken by the national government. As of mid-March, people who reside in the Netherlands are not allowed to come together in groups of or bigger than three people. Furthermore, people have to keep 1.5 meter distance from others who are not members of the same household. Researchers say that young adults are experiencing the biggest change in social activities, which is perhaps the reason why $49 \%$ of the young adults aged between 18 and 25 experience loneliness (Van 't Veld, 2020).

Additionally, in the Netherlands, it is common that students rent a student room. Those rooms are spread across the city. As there is not a real habit of campus life, loneliness is expected to be one of the effects of the corona measurements. Students told us that they are especially missing the 5 or 10 minutes before lectures. 
Social cohesion is of utmost importance, especially during times of social distancing. Social cohesion stimulates the learning process and has a positive impact on wellbeing. However, facilitating social cohesion through the internet might be a challenge. By making sure to strive for social cohesion, one can work towards online bonding, an online facilitation where people come together to talk with each other and share stories.

\section{Consequences for honors education and reasons for change}

The honors program of the department of Human Geography and Spatial Planning (part of the Faculty of Geosciences at Utrecht University) has an interdisciplinary honors community with disciplinary components. The Geosciences Honours College brings together around 100 students from different departments in honors seminars to discuss interdisciplinary topics. Within a department, such as Human Geography and Spatial Planning, disciplinary topics are covered. This coverage is done individually or in small groups. The full honors program consists of 45 ECTS-credits (in the European Credit Transfer and accumulation System one credit equals a workload of around 28 hours) of which 15 ECTS-credits are in addition to regular education. The community, soft skills, personal development, and interdisciplinary courses are on top of the regular program. Also, the obligatory international honors trip is in addition to the regular 180 ECTS-credits bachelor program. Those "extra" elements appear to be at risk during the pandemic, as most of the teachers currently lack time to organize honors education as they are already busy with the organization of the regular education. Maybe even honors education as such is at risk as obligatory courses and majors get priority. And yet, the honors students need their honors program and the honors community that may come with it.

The honors program of Human Geography and Spatial Planning students at the Geosciences Honours College also had to adapt to the new situation created by the ongoing pandemic. Due to the COVID-19 measures, the regular honors education had to be halted. This change means that, at the interdisciplinary level, no seminars for all students were organized. It seemed impossible to maintain or create the community. The authors wanted to change this.

Many students dealt with what is being called a cognitive overload: an information overload which causes information anxiety (Kirsh, 2000). This cognitive overload made it hard for students to focus on their studies. In addition, the online education was mainly focused on self-regulated learning; most of the time, students had to plan when they were going to watch the recorded lectures. Students therefore needed to be self-disciplined, which can be hard when you have to stay at home all day. By not having to attend obligatory lectures and not seeing students and teachers in real-life, education felt less personal. Consequently, some students felt less motivated. This effect was the reason for setting up meetings focused on the wellbeing of the students as well as on movies and books.

Honors education is often focused on challenging students and making sure they get the best out of their studies. Honors students can be characterized as motivated and hardworking students. However, during a pandemic with huge consequences, it may not be desirable or appropriate to ask students to challenge themselves even more; it is observed that most of the students have to deal with more stress than they normally have to. At the 
same time, distraction can help the students to relax a little bit and focus on other things besides the pandemic.

So, therefore, the authors came up with the plan to ask the students of Human Geography and Spatial Planning if they would like to continue disciplinary meetings. This continuation means online meetings with all cohorts, freshmen as well as seniors, together forming a smaller group of around 30 students, all situated in the Netherlands and speaking Dutch. The authors were especially worried about the freshmen in the honors program, as they entered the program in February 2020-just before the change to remote teaching. Therefore, the authors wanted to gather the students of all the different years. The honors students were enthusiastic about the proposal.

\section{The move towards online optional meetings focused on co-creation}

The authors were looking for ways to maintain or create community and social bonding while teaching remotely without any face-to-face contact. They wanted to create shared experiences. Therefore, the authors came up with the idea to create the opportunity for the honors students to design a series of optional online meetings, with emphasis on community building and with content offered through talking about movies and books. Together with the students, the authors decided to organize the online honors education by co-creation. Co-creating can empower students and make them feel more engaged (Bovill, 2013). The authors decided to create an online meeting every two or three weeks for all honors students of Human Geography and Spatial Planning-all cohorts together. They came up with the idea to have meetings with a combination of building knowledge and sharing, with an emphasis on the wellbeing of the students. The meetings were optional and had, in principle, nothing to do with the normal content of the honors program. A meeting would take 1.5 hours. During the meetings, one teacher (one of the authors) was always present.

Looking back, thanks to the students' engagement, meetings were held almost weekly. Students were well prepared. The topics were decided by the group. Every meeting was organized and prepared in co-creation by one or two students together with the authors. In total, seven meetings with honors students in Human Geography and Spatial Planning were organized and two meetings were held for all honors students of the Geosciences honors program. Students expressed the motivational and collaborative meetings were a pleasure to attend.

With a group of approximately 30 honors students, topics such as studying at home, being ill, knowing someone who is ill, and many other topics related to the coronavirus were discussed. Students also shared how to feel good, for instance, by growing vegetables, sports, walking, or talking with friends. Through online meetings on Microsoft Teams, the students discussed which movie, TV series and/or book they would like to discuss during the next online meeting. Besides content and duration, also availability and price were taken into consideration. Conversations continued afterwards via WhatsApp. Students came up with unpredictable and thought-provoking ideas.

Students prepared a discussion which they led during the online meeting. These discussions would be based around themes which in the movie, TV series, or book students watched or read before the online meeting. This organization worked out well, as the students indicated themselves. For instance, two students prepared a discussion through Mentimeter, an online 
platform which enables interaction by real-time voting. The students prepared questions about the two documentaries the whole group of students agreed to watch before the meeting. This way, there was an online, deep discussion between the students. Students expressed that they really liked the meeting and that they got new insights by talking about the documentaries. Also, they shared that discussing different point of views about the same movie was an eye-opener.

After each session, students discussed new topics and new dates. Additionally, students were also able to think of a creative way to make quick rounds checking in with people. Students indicated that they preferred to individually watch a documentary or a movie and have group meetings to talk about those visuals instead of individually reading a novel or non-fiction. Those conversations about the choice for a documentary, movie, or book were revealing. Students shared that they had to read a lot already for their studies. They preferred to have free choice what to read for leisure. They shared what kind of books they read or not and why. The group decided that the book club meetings were organized as a "hop on, hop off seminar" - making it more optional. To be clear, all meetings were optional. During the movie seminars, around 20 to 25 students joined; during the book seminars, 5 to 10 students would participate.

For the first book meeting, the group picked Humankind: A New History of Human Nature, written by Rutger Bregman. When the group talked about this book, the effects on themselves and others of the measurements because of the COVID-19 pandemic were also discussed. Students also connected the content of the book with actual ethical issues. The recent murder of George Floyd, who died after a police officer knelt on his neck for nine minutes, and the demonstrations that followed were discussed. At the end of the meeting, students shared that it was new to them to talk in such a way about a book and to share ideas about ethical questions relevant in their own lives.

The group picked the South Korean movie Parasite, awarded with four Oscars, as the first movie to watch. This movie was confronting. The group related the movie to the various effects of the pandemic on different groups. They discussed their own situation during the pandemic, and they also tried to compare their situation to the situation of others, like, for instance, refugees. There were discussions about ethics and inequality and inclusion. Also, geographical elements of the movie were discussed.

The group also decided to watch two episodes from a Dutch documentary series about China made by Ruben Terlou and Maaike Krijgsman. The conversation had geographical content. Students also talked about the way questions were asked by the documentary maker and if their views on China were altered. Students shared personal points of view. In addition, the students talked about whether they missed the "other" honors students from the other departments. They surely did. They were also interested in a conversation with a more interdisciplinary group. So, it was decided to organize a film meeting honors seminar for the whole honors group of the Geosciences Honours College. The students picked two episodes from the documentary Walking the Americas.

The interdisciplinary session was organized once on the Microsoft Teams platform and was visited by 38 students and 3 teachers. The language was English. Compared to the 
disciplinary session, less students shared easily, and periods of silence were longer. However, students stayed active during the two-hour optional session. They shared that they liked hearing new ideas, that they learned a lot, and that they were happy to meet and greet each other. Also, a new date was planned for the whole group for the end of June. In the meantime, the disciplinary group of Human Geography and Spatial Planning honors students were meeting almost weekly.

\section{Findings}

Although students did not meet physically, it became possible to create a feeling of community through sharing experiences. In co-creation, students and the teacher (honors director) created a new kind of online seminar.

It is interesting to note that the participation rate was high; almost all the students attended the online meetings, although the meetings were not obligatory and there were no consequences for not showing up. The students were satisfied with the online meetings, and they seemed to appreciate the moments in which they could share what they are currently experiencing during the pandemic. By creating an open and safe environment, students feel like sharing their stories. They connect through online bonding.

Students co-created the program, which seemed to empower them. They were engaged in the preparation, the meetings, and in the follow-up. Students wanted to see and speak to each other. They created and maintained a community by talking about their wellbeing and sharing ideas how to feel good. Students expressed that they got new insights by talking about the documentaries. Also, they shared that seeing different points of view about the same movie functioned as an eye-opener.

By sharing their ideas about a movie or documentary, critical thinking was needed. Students were confronted with different tastes and various ideas and learned to appreciate the dignity of difference. Also, content-wise, students talked in depth about the documentaries, like, for instance, about different ways the presenter of the documentary tells his story and why. The group talked about whether they could see and analyze how the documentary maker handled stereotypes and what kind of philosophy was shared with the audience. Students indicated that they were looking for connections between real life, ethical-and actual-issues and the documentary or movie. Therefore, students proposed that the coming documentary to be discussed be $13^{\text {th }}$ (Netflix) to get more insight into the institutionalized racism in the USA.

Students indicated that they enjoyed the meetings, and especially the community feeling. They showed that not only by words but also by actions. For example, already at the start of the co-creation sessions, students indicated whether they were going to join the first book meeting or not. However, some days before the actual book meeting via WhatsApp, all students informed each other and the teacher again. They said not only that they were not joining, but they also gave their personal reason why they were not joining.

\section{A look ahead in the future}

It is unsure how long it will take until students can come together in large gatherings. After the summer holidays, starting in July and ending in September, honors students can be 
asked again what they would like to do and how they would like to fill their honors program. It might be possible that most of the students have adapted to the situation and do not feel as distressed as they did at the beginning of the COVID-19 outbreak. Perhaps they would like to be challenged more.

The need for community building is evident. Honors students want and need an honors community. If this cannot be done on campus, people will look for online ways. Honors made a case: creating community during a pandemic is possible.

Online community building is not the same human experience as face-to-face community building. However, the book and movie meetings are an example of how community building may work while teaching remotely. Co-creating asks collaboration and specific preparation. It adds up. The authors can say that although the workload is heavy, co-creating these courses gives satisfaction. In addition, co-creation gives a (shared) feeling of responsibility and motivates students to attend the meetings.

\section{Conclusions}

Students are able and willing to co-create online honors courses during the pandemic. The focus on the wellbeing of the honors students makes sure students do not experience more stress by following the honors program. By giving the honors students the possibility to decide what they would like to do and how to discuss, and by sharing the responsibility, the online meetings are moments of connection and reflection. Instead of focusing on the requirements of the honors program, it is decided to focus on community building that is less related to the students' studies.

It is recommended for other institutions to see if it is needed to focus more on community building than on passing the requirements of the honors program. This reflection can be done by just asking the students what they would like to do and what they need to reach those goals. In times of a pandemic, it might be a good to focus on wellbeing instead of on challenging students. It might be wise to focus on community building instead of enhancing academics. It might be interesting to focus on actual ethical issues instead of programmed content and testing.

These times of the COVID-19 pandemic showcase the need for flexibility, community, and conversation. There is a need for an ability to adjust and to be open to act upon continuous change. It is unsure how the situation will be in the future and what the needs of the honors students will be. Therefore, by staying in touch with honors students and by continuously asking how they are doing and what their needs are, the honors program will be adapted to the new situations and needs of honors students.

\section{Acknowledgements}

We want to thank all honors students of the Geosciences Honours College, University Utrecht, the Netherlands and the Human Geography and Spatial Planning honors students in particular. 


\section{References}

Bovill, C. (2013). Students and staff co-creating curricula: An example of good practice in higher education? In E. Dunne \& D. Own (Eds.), The Student Engagement Handbook: Practice in Higher Education, (pp. 461- 475). Bingley: Emerald Publishing.

Kirsh, D. (2000). A few thoughts on cognitive overload. Intellectica, 1(30), 19-51.

Utrecht University (n.d.). Cijfers en feiten. Retrieved on May 16, 2020 from: https://www.uu.nl/organisatie/profiel/cijfers-en-feiten

Veld, A. van 't, Beerepoot, R., Kanne, P., Stel, M., Vries, P. de, \& Kuttschreuter, M. (2020). Het corona- en het eenzaamheidsvirus (043). Amsterdam: I\&O Research.

Wolfensberger, M.V.C. (2012). Teaching for Excellence: Honors Pedagogies Revealed. Münster: Waxmann. 